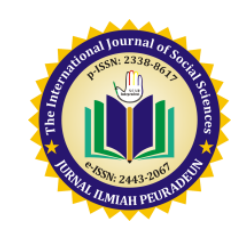

\title{
THE FACTORS THAT EFFECT ON INTERNAL AUDITOR INDEPENDENCE IN THE ACEH BANKING SECTOR
}

\author{
Dwi Meilvi Nasvita \\ Masters of Accounting, Postgraduate Program, Syiah Kuala University, Banda Aceh
}

Received: Apr 25, 2016

Accepted: July 11, 2016

Published: Sep 28, 2016

Article Url: https://journal.scadindependent.org/index.php/jipeuradeun/article/view/108

\begin{abstract}
This study aimed to examine the factors that effect on internal auditor independence of the internal auditor, namely the competence of internal auditors, management intervention, employee participation and regulation of the company. The sample of this research is internal auditing staff at banks of Aceh. Data were collected through the distribution of questionnaires to respondents using multiple linear regression analysis. The results showed that all factors have influences on the independence of internal auditor, simultaneously or partially. While auditor competence, employee participation, and company regulation have positive influence, management intervention has a negative influence on the independence of the internal auditors.
\end{abstract}

Keywords: Internal Auditor Independence, Auditor Competence, Employee Participation, Company Regulation. 


\section{A. Introduction}

Internal auditors have a role as a controller that ensures that all elements of the company have a common understanding of the objectives and the risks faced by the company (Tugiman, 1997). Internal auditors are not involved in the works of either executives or actors of bank operations because internal auditors are separate of a company's operational activities (Mulyadi, 2002). Therefore, an internal auditor must maintain independence from the influence and intervention of various parties. The independence of the internal auditor who owned the audit will produce quality and reliable audits.

The independent appraiser refers to an auditor who uses an objective standpoint in the conduct of the audit, the evaluation of audit results, and report of the audit (Arens et al., 2008). The independent internal auditor according to Sawyer et al. (2005) is a professional auditor who has the freedom to fulfill their professional obligations, express objective opinions, unbiased and unrestricted, and report the problem objectively, not taking order from the executive or the agency.

Meanwhile, the independence of the internal auditor according to Kumaat (2011) is an internal auditor alignment on factual truth. This independence is key and at the same time limit for internal auditors in performing tasks under their responsibility, which includes supervision investigation object and supervision result report (Mulyadi, 2002).

This is in accordance with the opinion of Mautz and Sharaf (1961) who said one of the key factors of the auditor is independence, without which the audit report is not reliable. However, Bazerman's perspective from the psychological point of view regarding auditor independence suggests that efforts to achieve independence are impossible and the current approaches existing within auditing profession are naive and sometimes conflicting with theories, and therefore there are many problems faced by auditors (Kasidi 2007, p.15). Bazerman explained that based on the evidence of psychological research showing that a strong human desire affect how to interpretation the information, even if it means trying to be objective and impartial. 
Internal auditors are not always in a strong position to defend their independence (Al-Twaijry et al., 2004). According Cooper et al. (1994) internal auditors are not be seen as a proper profession by all people, including some of their own company managers (Peursem and Pumphrey, 2005: 2). This can lead to unfavorable judgment on their quality when compared with the external auditors. Brody and Lowe (2000) found the possibility that the relationship of internal auditors and management consultants who will be providing services rather than as an independent appraiser.

This study examined several factors that influence the independence of the internal auditor in carrying out their responsibilities, namely the competence of internal auditors, management intervention, employee participation and regulation of the company. The influence of these factors on the independence of the internal auditor will be tested in the scope of the audit and audit qualities are produced.

The first factor to influence the independence of the internal auditor is the auditor competence. According to Bailey (2010) competence is the ability that is needed by the auditor to perform certain tasks. Lasmahadi (2002) defines competence as the personal aspects of a worker that allow him to achieve his best performance (Halim et al., 2014: 65). This competence is comprised of planning, knowledge, experience and consistency. This is in accordance with Ashton's suggestion (1991) that in the psychology literature, specialized knowledge and extensive work experience are important factors that will increase the competence of the internal auditor (Alim et al., 2007,p.6).

Research conducted Alzeban and Gwiliam (2012) shows some evidence that competence has positive influence on the independence of internal auditor. This is similar to the research conducted Jamaluddin, et al., (2014) which states that an internal auditor should not only be complacent with the achievement of their capacity only but should also continue to upgrade the his existing capacity to maintain his consistency professionally in order to keep his independence.

The second factor that influences the independence of the internal auditor is the management intervention. According to Tugiman (1997) the interventions from the management on the internal auditor is an attempt 
to politicize the auditor's functions and undermine his credibility as a profession. The management must expect the internal audit report to bring out the best outcome and minimize the weaknesses that might be captured by the internal auditors (Sawyer et al., 2006). Davis and John (1985) argues that conflicts arises from disagreement over goals or from the method used to achieve them. Conflicts will be an ethical dilemma for the auditor to choose between his independence and integrity and financial reward that might be offered (Faisal, 2007).

Nichole and Price (1976) found that when the auditor and management do not reach agreement in the aspect of performance, it may lead to management's forcing auditors to take action against the standards, including in the expression of opinions (Alim et al., 2007: 3). This situation was also found in a research conducted Peursem and Pumphrey (2005) which suggests that it is difficult to control the internal auditor's involvement with management. A causal relationship between internal auditors and audit committee is supposed to neutralize the role dilemma faced by an internal auditor to be independent.

A third factor influencing the internal auditor is employee participation. Participation is mental and emotional involvement of the people in group situations which encourages them to contribute to the objectives of the group and commit to various tasks in the effort of achieving that goal (Davis and John, 1985). A more simplified definition was proposed by Djalal and Supriya (2001) which suggests that participation can also refers to decision makers, who are involved in providing advice and opinions, items, skills , materials and services.

The conflict between the internal auditors and employees often occur because of the duties and authority of the internal auditor who are demanded to be independent and professional, creating an impression of stiffness for employees in tolerating their intentional or unintentional misconducts (Tunggal, 1992). Argyris (1978) cited in Anoraga (2009) describes how the internal auditor position themselves as "watchdogs" for the company. Their success is at the cost of other employees. Employees' misconducts found by the internal auditors are a display of their good performance to the management. 
In addition to supervisory functions, an internal auditor also needs to be social creatures to maintain good relations with other colleagues. According Brehm and Kassin (1990), to maintain good relations, an auditor will tend to adjust themselves to the situation at the workplace (Faisal, 2007: 7). Ponemon (1992), mentions that the internal auditors are vulnerable to pressure from colleagues within the company (Faisal, 2007, p.3). Therefore, the internal auditors need to attract some participation from employees to accomplish their duties. Sord and Welsch supports that greater employee participation will result in better morale and greater initiative from the internal auditors (Noor, 2007: 5).

The fourth factor is the regulation of the company. The regulations of companies are written regulations prepared by the employer which contains the terms and conditions of employment and rules of the company. Regulation of banks governs banking institutions along with their products and services. The purpose of the regulation in the banking industry is to protect customers and increase public confidence in the products of the banking industry (Idroes, 2011).

Each company has an internal audit policies and regulations which are relevant toits need and interest (Rizky and Majdi, 2008). The independence of the internal auditor in the company's activities must be supported by the company's commitment to impose regulations in accordance with Standard IIA and a commitment to have an internal audit guideline, audit charter and audit quality assurance (Muqattash, 2011). The audit committee, especially those that include external directors, assists internal auditors in maintaining their independence (Spira and Page, 2003; Vanasco, 1996; Goodwin and Yeo, 2001 cited in Peurseum and Pumphrey, 2007: 4).

Based on the discussion of the previous studies, this study aimed to test the hypothesis to find out the influence of the independent variables which include the auditor competence, management intervention, employee participation and company regulation on the independence of the internal auditors (the dependent variable). The results showed that the competence of auditors, management intervention, employee participation, and company regulation have influences on the independence of internal auditors, simultaneously or partially. 


\section{B. Method}

This research was conducted on the internal auditors of banks with branch coordinating offices that have internal auditors who live in the province of Aceh. The unit of analysis is the 15 banks with 66 respondents. Attitude scale model used in this study is a Likert scale with 5 point intervals from 1 to 5 expressing strong agreement to strong disagreement. The returned questionnaires were analyzed using SPSS (Statistical Package for Social Science).

To analyze the data multiple linear regressions were used which examined the influence of dependent variables on independent variables partially and simultaneously. The following is the multiple linear regressions that were used.

$$
Y=\alpha+\beta_{1} X_{1}+\beta_{2} X_{2}+\beta_{3} X_{3}+\beta_{4} X_{4}+\varepsilon
$$

Where:

$$
\begin{array}{ll}
\mathbf{Y} & =\text { The independence of the internal auditor } \\
\boldsymbol{\beta}_{1}, \boldsymbol{\beta}_{2}, \boldsymbol{\beta}_{3}, \boldsymbol{\beta}_{4} & =\text { The regression coefficient } \\
\mathbf{X} \mathbf{1} & =\text { Auditor competence } \\
\mathbf{X} \mathbf{2} & =\text { Intervention Management } \\
\mathbf{X} 3 & =\text { Employee participation } \\
\mathbf{X} 4 & =\text { Company regulation } \\
\mathbf{E} & =\text { Error term }
\end{array}
$$

This research examined the influence of dependent variables on independent variables. The independent variables which include the auditor competence $\left(X_{1}\right)$, management intervention $\left(X_{2}\right)$, employee participation $\left(X_{3}\right)$ and company regulation the $\left(X_{4}\right)$, while the dependent variable are independence of the internal auditors $(Y)$.

\section{Research Finding}

Questionnaires were distributed to 66 respondents, with a return rate of $76 \%$ (50 questionnaires). Results of hypothesis testing using SPSS are shown in Table 1. 


\section{Table 1}

Regression Test Results

\begin{tabular}{|l|l|c|c|c|}
\hline Variables & \multicolumn{1}{|c|}{ Variable names } & $\begin{array}{c}\text { Regression } \\
\text { coefficient }(\boldsymbol{\beta})\end{array}$ & $\mathrm{R}$ & $\mathrm{R}^{2}$ \\
\hline & Constants & 12,498 & & \\
\cline { 1 - 2 } $\mathrm{X}_{1}$ & Internal Auditor Competence & 2,100 & \multirow{3}{*}{0,624} & \multirow{2}{*}{0,389} \\
\hline$X_{2}$ & Management Intervention & $-0,166$ & & \\
\hline$X_{3}$ & Employee Participation & 0,364 & & \\
\hline$X_{4}$ & Company Regulation & 0,174 & & \\
\hline
\end{tabular}

Source: Processed Primary Data (2016)

Based on Table 1 multiple linear regression function was written as follows:

$$
Y=12.498+2.100 X_{1}-0.166 X_{2}+0.364 X_{3}+0.174 X_{4}+\varepsilon
$$

The regression function shows the result of the research. The constant is 12,498 , meaning that if the auditor competence, management intervention, employee participation, and company regulation is considered to be constant, then the value obtained from variable independence of internal auditors is 12,498 on a Likert scale unit. The correlation coefficient (R) of 0,624 shows that the degree of relationship (correlation) between the independent variables and the dependent variable is equal to $62.4 \%$. The coefficient of determination ( R2) of 0,389 means that the independence of auditors of banks in Aceh is influenced by internal auditor competence, management intervention, employee participation and company regulation which is 38.9\%, while $61.1 \%$ are influenced by other variables not included in this study.

\section{Discussion}

1. The Influence of Internal Auditor Competence, Management Intervention, Employee Participation and Company regulation on the Independence of Internal Auditors

The hypothesis states that the auditor competence, management intervention, employee participation and company regulation simultaneously influence the independence of the internal auditor. Testing was done by looking at the regression coefficients of all independent variables, provided that if at least there is a regression coefficient $(\beta \mathrm{i})$ that is not equal to zero the first hypothesis cannot be rejected/ accepted which means the internal auditor 
competence, management intervention, employee participation and company regulation influence the independence of auditors.

\section{The Influence of Internal Auditor Competence on the Independence of Internal Auditors}

The first factor was tested to see if competence influences the independence of internal auditors; tested to find out its regression coefficient $(\beta 1)$ for this variable. The regression coefficient $(\beta)$ for this variable was obtained at 0,2100 or $\beta \neq 0$. The hypotheses testing result showed that $\beta 3 \neq 0$ and accept the hypothesis.

This result is consistent with Alzeban and Gwilliam (2012) stating that the competence of auditors has positive influence on the independence of the internal auditor to produce a quality audit. Another study from Jamaluddin et al., (2014) also recommends that training on an ongoing basis in order to increase the competence of internal auditors in maintaining the quality of the audit is necessary.

\section{The Influence of Management Intervention on the Independence of Internal Auditors.}

The second factor was examined to find out if management interventions influence the independence of the internal auditor; tested to find out the regression coefficient ( $\beta 2$ ) for variable management intervention. Regression coefficient $(\beta)$ variable management intervention competence was obtained at $-0,166$ or $\beta \neq 0$, meaning that interventions influence the independence of the internal auditor. Low intervention of management will increase the independence of internal auditors.

Management intervention in banking in the province have an influence on the independence of the internal auditor, but the effect is only $16,6 \%$. Peursem and Humphrey (2005), which shows that it is difficult to control the internal auditor involvement with management. Research conducted Jamaluddin, et al. (2014) gives the result that the relationship of role conflict and ambiguity internal auditor with management have an influence on the independence of the internal auditor. Therefore, the level of support and management role for the internal audit function is a powerful factor and key to 
the effectiveness of the internal audit function so that the state of independence of the internal auditor is maintained (Alzeban and Gwilliam, 2012).

\section{The Influence of Employee participation on the Independence of Internal Auditors}

The third factor was tested to see if employee participation influences the independence of internal auditors; tested to find out its regression coefficient $(\beta 3)$ for this variable. The regression coefficient $(\beta)$ for this variable was obtained at 0,364 or $\beta \neq 0$. The hypotheses testing result showed that $\beta 3 \neq 0$ and accept the hypothesis. These test result shows that the greater employees participation and cooperation with the auditor in a company, the independent the internal auditors will get.

This is in accordance with what is revealed by Ponemon (1992) that internal auditors are vulnerable to colleague pressure within a company (Faisal, 2007: 3). Sord and Welsch reinforces that higher participation would result in a better moral and hence higher initiative of the internal auditor (Noor, 2007: 5).

\section{The Influence of Company Regulation on the Independence of Internal Auditors}

The fourth factor was examined to see if company regulations influence the independence of the internal auditor; tested to find out the regression coefficient $(\beta 4)$ for variable company regulation. The regression coefficient $(\beta)$ for variable company regulations was obtained by 0,174 or $\beta \neq 0$. This result shows that $\beta 4 \neq 0$ and accepts the hypothesis. This means that company regulations influence the independence of the internal auditor. It shows that the more comprehensive the regulations at a company, the more independent the internal auditors will get.

This is consistent with the results of the research conducted Muqattash (2011) which shows regulation has an influence on the independence of the internal auditor. Muqattash emphasize the existence of audit committees that are considered important to maintain objectivity will improve the integrity and credibility of the internal auditors.

Research conducted Jamaluddin et al., (2014) also explains that the regulation is also made as a reference to avoid conflicting of the desire of 
management with the duties and authority of the internal auditors. With the regulation, auditors can act independently in accordance with the goals of the company without restriction

\section{E. Conclusion}

All variables tested in this study, namely: auditor competence, management intervention, company regulation, and employee participation influence the independence of the internal auditor either simultaneously and partially. The limitations in this study is the conclusion drawn based only on data collected through questionnaires, which could lead to problems if the respondents concealed their actual state of attitude. This cannot be controlled by the researcher because it is beyond the ability of researchers.

This research used only four independent variables; there are still other variables that can influence the independence of internal auditors. This study proves the partial influence of variable management interventions in the internal auditor's independence variable $16,6 \%$ and the effect of variable company regulation on the independence of the internal auditor is $17,4 \%$. Both of these independent variables are likely related to internal bank secrecy so that respondents were probably not able to disclose their attitude on two other independent variables, the auditor competence and employee participation.

The conclusions of this study indicate that there is influence of the auditor competence, management intervention, employee participation and company regulation on the independence of internal auditors. Therefore, internal auditors of banks in Aceh should pay more attention to these variables so as to maintain their independence. Further research can replicate this study by adding other variables that might influence the independence of internal auditors. Research can be developed by including only respondents from a specific bank which has sufficient population and sample using qualitative approach to produce research with more profound and satisfactory results. 


\section{Bibliography}

Alim, N.M., Trisni, H., \& Liliek, P. (2007). Pengaruh kompetensi dan independensi terhadap kualitas audit dengan etika auditor sebagai variabel moderasi. Simposium Akuntansi X. Unhas Makassar.

Al-Twaijry, A. A. M., Brierley, J.A., \& Gwilliam, D. R. (2004). An examination of the relationship between internal and external audit in the Saudi Arabian corporate sector, Managerial Auditing Journal, 19(7), 929-944.

Alzeban, A., \& Gwiliam, D. (2012). The role and practice of internal audit in the saudi public sector. Working Paper. A22. King Abdul Aziz University.

Anoraga, P. (2009). Manajemen bisnis. Jakarta: PT. Rineka Cipta

Arens, A.A., Randal. J., Beasley., \& Mark S. (2008). Auditing dan jasa assurance (Pendekatan terintegrasi). Jakarta: Erlangga.

Bailey, J.A. (2010). Core competencies for today's internal auditor. Florida: The IIA'S Research Fondation.

Brody, R. G., \& Lowe, D. J. (2000). The new role of the internal auditor: implications for internal auditor objectivity. International Journal of Auditing, 4, 169-176.

Davis, K., \& John, W.N. (1985). Perilaku dalam organisasi. (Edisi 9). Terjemahan Agus Dharma. Jakarta : Erlangga.

Djalal, F., \& Supriadi, D. (2011). Reformasi pendidikan dalam konteks otonomi daerah. Jakarta: Depdiknas Bapenas Adicitakaryanusa.

Faisal. (2007). Investigasi tekanan pengaruh sosial dalam menjelaskan hubungan komitmen dan moral reasoning terhadap keputusan auditor. Simposium Nasional Akuntansi X. Unhas Makassar.

Idroes, F. N. (2011). Manajemen risiko perbankan. Jakarta: Rajawali Pers.

Halim, A., Sutrisno \& Achsin, M. (2014). Effect of competence and auditor independence on audit quality with audit time budget and professioanl commitmen as a moderation variable. Journal of Business and Management Invention. 3, 64-74.

Jamaluddin., Muhammad. A., Mediaty, \& Syarifuddin. (2014). Effects of independence mediation on the influence of role ambiguity, role conflict and auditors competence toward internal audit quality. Journal of Research in Business and Management. 2, (10). 33-44. 
Kasidi. (2007). Faktor-faktor yang mempengaruhi independensi auditor: Persepsi manajemen keuangan perusahaan manufaktur di Jawa Tengah. Tesis. Semarang: Program Pascasarjana Universitas Diponegoro

Kumaat, V. G. (2011). Internal audit. Jakarta: Erlangga.

Madung, O. G. (2014). Paradigma Holisme Hegelian dan Kritik Atas Liberalisme. Jurnal Ilmiah Peuradeun, 2(2), 45-60.

Mautz, R.K., \& Hussein A.S. (1961). The Philosophy of Auditing. Florida: American Accounting Association.

Mulyadi. (2002). Auditing. Jakarta: Salemba Empat.

Muqattash, R. (2011). The effect of the factors in the internal audit departmen on the bank operating in the United Arab Emirates. Journal of International Management Studies. 6, (3). 92-100.

Noor, W. (2007). Desentralisasi dan gaya kepemimpinan sebagai variabel moderating dalam hubungan antara partisipasi penyusunan anggaran dan kinerja manajerial. Simposium Akuntansi X. Makasar.

Peursem, K.V., \& Pumphrey, L.D. (2005). Internal auditors and independence: An agency lens on corporate practice. Financial Reporting, Regulation and Governance. Departemet of Accounting, 4:2.

Rizky, A., \& Majdi, N. (2008). Bank bersubsidi yang membebani. Jakarta: E Publishing.

Safrina, S., \& Saminan, S. (2015). The Effect of Model Problem Based Learning (PBL). Jurnal Ilmiah Peuradeun, 3(2), 311-322.

Sari, N. (2014). Re-Design Kurikulum Ekonomi Syariah Perguruan Tinggi Agama Islam. Jurnal Ilmiah Peuradeun, 2(3), 135-154.

Sawyer, L.B., Dittenhofer, M.A., \& Scheiner, J.H. (2005). Audit internal sawyer. (Edisi 5). Jakarta: Salemba Empat.

(2006). Audit internal sawyer. (Edisi 5). Jakarta: Salemba Empat.

Tugiman, H. (1997). Standar Profesional Audit Internal. Yogyakarta: Kanisius.

Tunggal, A. W. (1992). Management audit. Jakarta: PT. Rineka Cipta. 